\title{
A new oriental species of Thecophora RoNDANI (Diptera: Conopidae) and first records of Thecophora caenovalva (KRÖBER) from Japan
}

With 9 figures and 1 table

Jens-HeRMann Stuke ${ }^{1}$

${ }^{1}$ Roter Weg 22, 26789 Leer, Germany. - jstuke@zfn.uni-bremen.de

Published on 2017-12-08

DOI: $110.21248 /$ contrib.entomol.67.2.207-212'

\section{Abstract}

Thecophora bartaki spec. nov. is described from Laos and Thecophora caenovalva (KRöBER) is reported from Japan.

\section{Nomenclatural Acts}

Thecophora bartaki spec. nov. - urn:lsid:zoobank.org:act:D0069884-865A-46CC-92EE-DE874AA6EDD6

Key words

Diptera, Conopidae, Thecophora, new species, Laos, Japan

\section{Zusammenfassung}

Thecophora bartaki spec. nov. wird von Laos beschrieben und Thecophora caenovalva (KRöBER) wird aus Japan gemeldet.

\section{Introduction}

Thecophora RoNDANI is taxonomically one of the most difficult Conopid genera. Some 39 valid species are currently known worldwide. These flies are not rare but due to their small size and generally dark appearance they tend to be only rarely collected and are easily overlooked by dipterists who do not focus on Conopidae. While there is a large amount of material available in museums from the Nearctic and West Palaearctic regions, only relatively few specimens are available from the East Palaearctic and Oriental regions. The lack of material from these regions is one reason why it is so difficult to achieve a satisfactory understanding of the taxonomy of the genus. Another reason is the lack of suitable identification features. To date the most reliable character for species diagnosis is the shape of the female theca. The male genitalia of Thecophora hardly differ between the species, and more effort is needed to find other reliable identification characters. Dusting patterns and colouration of the legs have often been used to distinguish species in the past, but these characters are very variable. Leg colouration must be used with caution, whilst dusting patterns depend on the condition of the specimen and may also vary intraspecifically. 
Following receipt of some Thecophora from Japan, some specimens were found which do not fit with any known Palaearctic species. Surprisingly, however, these specimens are similiar to another hitherto unidentified specimen from Laos. Both appeared to fit broadly with the description of Thecophora caenovalva from Taiwan (KRöBER, 1916) and therefore a study of the holotype of the latter became necessary. This paper presents the results of this examination and sets out the description of a new species, together with some new faunistic records of T. caenovalva.

\section{Materials and methods}

The nomenclature of species is adopted from STUkE (2017). The terminology for describing the morphological characters is based on CUMming \& Wood (2009).

\section{Results}

\section{Thecophora bartaki spec. nov.

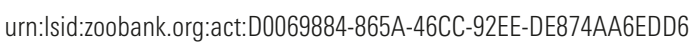 (Figs 1-6)}

Holotype 9 : (1) "Laos, Vientiane pr. / $55 \mathrm{~km} \mathrm{~N}$ Vientiane / 18²7'N, 102 ${ }^{\circ} 49^{\prime} \mathrm{E} / 100$ m, 4-18.V.2005 / Petr KRESL leg."; (2) "Holotypus / Thecophora bartaki / spec. nov. 우 / det. STUKe 2017”.

The holotype is deposited in the collection of the Czech University of Life Sciences, Czech Republic, Prague (CULSP). The specimen is glued on a card point and is in good condition (Fig. 1).

Description of holotype (female): Length $5.7 \mathrm{~mm}$. Wing-length $4.4 \mathrm{~mm}$. Head-height $1.4 \mathrm{~mm}$. Antenna light brown to orange, basal flagellomere blackish brown distally and dorsally. Arista with 1 brown aristomere situated dorsally on the basal flagellomere. Aristomere slightly shorter than basal flagellomere, broad basally, and becoming abruptly narrower in the apical 3/4. Scape distinctly longer than broad, apically with a few setae which are shorter than the scape. Pedicel about twice as long as high, covered with short black setae and dorsally with longer black setae. Basal flagellomere distinctly longer than high, slightly shorter than pedicel. Lunule between base of antennae and ptilinal suture completely invaginated. Eyes reddish brown. Posterior margin of eye convex, without any indentation. Gena below eye less than half of eye-height. Ocellar tubercle with three distinct brown ocelli. Ocellar triangle evident, brown, about $1 / 2$ of frons length. Frons black, only narrowly yellow anteriorly. Frons longer than broad, flat, not projecting above eyes. Obvious silver dusting laterally at eye margin, and an indistinct golden to brown, more or less v-shaped patch in front of ocellar triangle. Black hairs all over frons, which might include some frontal and orbital setae. Face orange-brown. Face distinctly silvery white dusted, facial grooves shining. Gena and facial ridge with scattered black hairs. Distinct facial grooves reaching to a small ventral facial tubercle. Facial grooves broader than maximum width of an antenna. Facial carina not evident. Ptilinal suture stretching beneath antennal bases. Postcranium not obviously invaginated, black dorsally and becoming brown ventrally. Adjacent to the ventral posterior margin of the eye there is a stripe of dense silver dusting. Postgena distinctly silver dusted, rest of postcranium slightly dusted to shining. Postcranium with black hairs, although with no hairs on a small area adjacent to the eye margin and on the bottom portion of the postcranium. Proboscis black. An indistinct reddish brown spot between frontoclypeal membrane and mouth edge. Frontoclypeal membrane basally as broad as mouth opening, yellow and distinctly separated from the yellow clypeus. Palps longer than scape, blackish brown, hardly widened distally, and covered with long black hairs. Labium about as long as head-length, projecting out of the mouth opening and hardly thickened basally, the anterior section not fused into a tube. Labellum as long as labium, with no apical division recognised. Labellum slightly narrower than adjacent haustellum, and covered with scattered hairs. At least three pairs of pseudotrachaea on the labellum. Head with 2 distinct ocellar setae, 1 postocellar seta, and 1 distinct medial postocular seta.

Thorax blackish brown. Thorax completely grey dusted, without any shining areas. Postpronotum, scutum in front of scutellum and in front of transverse suture, anterior half of anepisternum and katepisternum posterodorsally, obviously densely grey dusted (Fig. 2). Presternum is a narrow sclerotised stripe. Basisternum narrow, and narrowing to a tip, with 4 black setulae apically. No setulae recognised ventrally at proepisternum but a few hairs dorsally. Scutellum covered with long black hairs and with 1 pair of scutellar setae. Scutum with short black hairs, as long or shorter than tibia diameter. No distinct postpronotal seta. 2 notopleural, 1 supra-alar, 2 postalar, and 1 praescutellar setae. 1 black seta posterodorsally and several setae ventrally on katepisternum. Metakatepisternum without setae. Anepisternum and anepimeron hairless and without setae. Wing slightly tinged brownish. Veins yellow basally and black apically. Radial-medial-crossvein $\mathrm{r}-\mathrm{m}$ complete. Basal-medial-cubital-crossvein bm-cu incomplete. Radius $\mathrm{R}_{1}$ and subcosta sc terminate together in the costa, well before the end of radius $R_{2}$. $R_{1}$ meets subcosta where terminating in the costa. Radius $\mathrm{R}_{4+5}$ with a shallow and even curve in the distal section which is directed towards the wing tip. Radial cell $r_{4+5}$ open, vein $R_{4+5}+M$ not expressed. Cubital cell cup elongated (distinctly longer than vein $\mathrm{A}_{1}+\mathrm{CuA_{2 }}$ ) and pointed distally (cubitus $\mathrm{CuA}_{2}$ and anal vein $\mathrm{A}_{1}$ meet at an acute angle). Vein $\mathrm{A}_{1}+\mathrm{CuA}_{2}$ only just reaching hind margin of wing. Cubital vein $\mathrm{CuA}_{1}$ and crossvein $\mathrm{bm}-\mathrm{cu}$ distinctly separated. Upper and lower calypters whitish 
brown, calypters with long white hairs on margin. Alula broad (about 2 times broader than long), with long hairs on posterior margin. Vena spuria pronounced in cubital cell cup only. Haltere yellowish white with a barely contrasting yellowish brown base. Base and stem of haltere each with areas of sensillae. No hairs recognised at knob of haltere. Legs orange-brown, with hind coxa, apical third of femora and apical tarsomeres brown. Legs slightly dusted to shining. Posterior surfaces of fore and middle tibiae without obvious dusted fields distally. Legs all with long, semiadpressed or erect black hairs. Areas with dense brown hairs ventrally at tip of fore tibia and ventrally and posteriorly at tip of hind tibia. Middle femur posteriorly without any long hairs. Hind femur anterodorsally and posterodorsally without outstanding long hairs. 1 indistinct praeapical bristle dorsally on tibiae. Fore and middle tibiae basally on ventral surface with one distinct line of small thick adpressed black bristles. All femora distally on ventral surface with two parallel lines of small thick black bristles. Fore coxa without outstanding black setae. Middle and hind coxae with some distinct strong lateral setae which are about as long as diameter of basal hind tibia. Hind femur not obviously thickened in basal half. Pulvilli yellow. Claws yellow, with black tips. Empodium yellowish brown, about as long as pulvilli.

Abdomen blackish brown (Fig. 5), covered with black hairs only. Tergites 1-5 slightly dusted. Tergites 2-4 with grey dusted spots laterally on the hind margins. Tergite 5 shining to subshining. Abdomen not parallel sided, with maximum width at segment 4 . Length: maximum width of tergite $2=1.0$; length : maximum width of tergite $3=0.7$. Tergite 5 and sternite 5 separated, with an obviously projecting theca below (Fig. 4). Theca spoon-shaped, appearing slender and 'thorn-shaped' in side-view, and as long as tergite 6 is deep (Fig. 6). Anterior surface of theca orange-brown, without hairs. Apical third of posterior surface of theca with 8 horizontal lines of close-set, short, blunt spicules. Sternite 6 almost completely covered with short, blunt spicules which are almost entirely arranged in 11 horizontal lines.

Diagnosis: Males of T. bartaki are unknown and therefore cannot safely be assigned to species. Due to its large theca (Fig. 4) the female of T. bartaki is clearly similar to T. caenovalva. The separation of females of T. caenovalva and T. bartaki is further summarised in Table 1.

With the exception of T. caenovalva and T. bartaki, there are only six other Thecophora species known from the Oriental Region (STUke 2017). None of these species resembles T. bartaki due to (a) the large, spoon-shaped theca with its anterior surface completely light brown; (b) its characteristic dusting pattern of the scutum, with strong dusting in front of the scutellum, on the postpronotum and in front of the transverse suture and scutum without any longitudinal lines of dusting (Fig. 2); (c) the almost completely yellow legs (Fig. 1); (d) the yellow wing base (Fig. 1); and (e) tergites 2-4 with lateral grey dusting at the posterior margin (Fig. 5).

Tab. 1: Separation of females of Thecophora caenovalva (KRÖвER) and Thecophora bartaki spec. nov.

\begin{tabular}{|l|l|}
\hline T. caenovalva (KRÖBER) & T. bartaki spec. nov. \\
\hline Scutum evenly dusted (Fig. 8). & $\begin{array}{l}\text { Scutum obviously more strongly dusted in front of scutellum, } \\
\text { on postpronotum and in front of transverse suture (Fig. 2). }\end{array}$ \\
\hline Anepisternum ventrally with a small shining patch. & Anepisternum completely dusted. \\
\hline $\begin{array}{l}\text { Abdomen parallel sided, segment 2 about as broad as } \\
\text { segment 4. }\end{array}$ & $\begin{array}{l}\text { Abdomen not parallel sided, segment } 4 \text { broader than other } \\
\text { segments (Fig. 5). }\end{array}$ \\
\hline $\begin{array}{l}\text { Theca obviously shorter than height of tergite 6 } 6 \\
\text { (Fig. 9), blunter and more 'hoof-shaped' in side-view. }\end{array}$ & $\begin{array}{l}\text { Theca about as long as height of tergite 6 (Fig. 4), more slen- } \\
\text { der, pointed and 'thorn-shaped' in side-view. }\end{array}$ \\
\hline Theca apically with 5 horizontal lines of black spicules. & $\begin{array}{l}\text { Theca apically with } 8 \text { horizontal lines of black spicules } \\
\text { (Fig. 6). }\end{array}$ \\
\hline Sternite 6 with 5-6 horizontal lines of black spicules. & Sternite 6 with 11 horizontal lines of black spicules. \\
\hline
\end{tabular}

Etymology: This species is dedicated to Prof. Dr. MiroSLAV BARTÁK (Prague), who sent the holotype specimen to me for examination. I am personally very grateful to Miroslav Barták, who has supported my work with Conopidae and other Diptera families over many years, and has loaned me a huge quantity of rare flies.

Distribution: Thecophora bartaki is only known from the locus typicus in Laos.

\section{Thecophora caenovalva (KRÖBER, 1916) (Figs 7-9)}

Holotype examined: 1 o with these labels: (1) "Tappani / Formosa / H. SAUTER 1910"; (2) "7. III."; (3) "coll. Lichtwardt”; (4) "Occemyia ㅇ / caenovalva KRB. / O. KRÖBER det. 1914"; (5) "Holotypus". The specimen is deposited in the collection Senckenberg Deutsches Entomologisches Institut, Müncheberg (SDEI).

There is a $o^{*}$ in the SDEI wrongly labelled as "Type", bearing labels as follows: (1) "Tappani / Formosa / H. Sauter 1910”; (2) “7.IV.”; (3) “coll. LichtwardT"; 


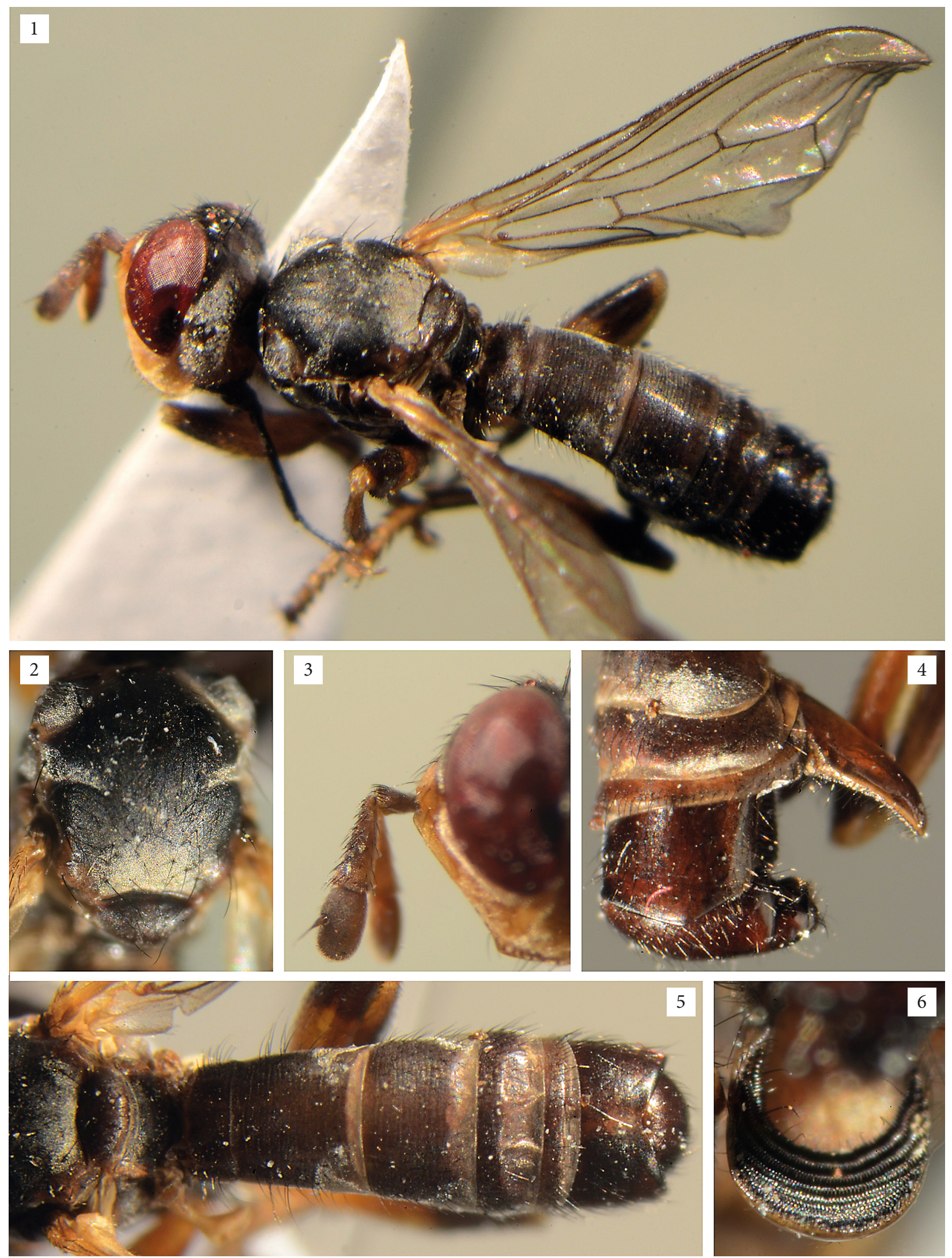

Figs 1-6: Thecophora bartaki spec. nov. (holotype). - 1 habitus, dorsolateral view; - 2 scutum, dorsal view; - 3 head, lateral view; -4 theca, lateral view; -5 abdomen, dorsal view; -6 theca, posterior view. 


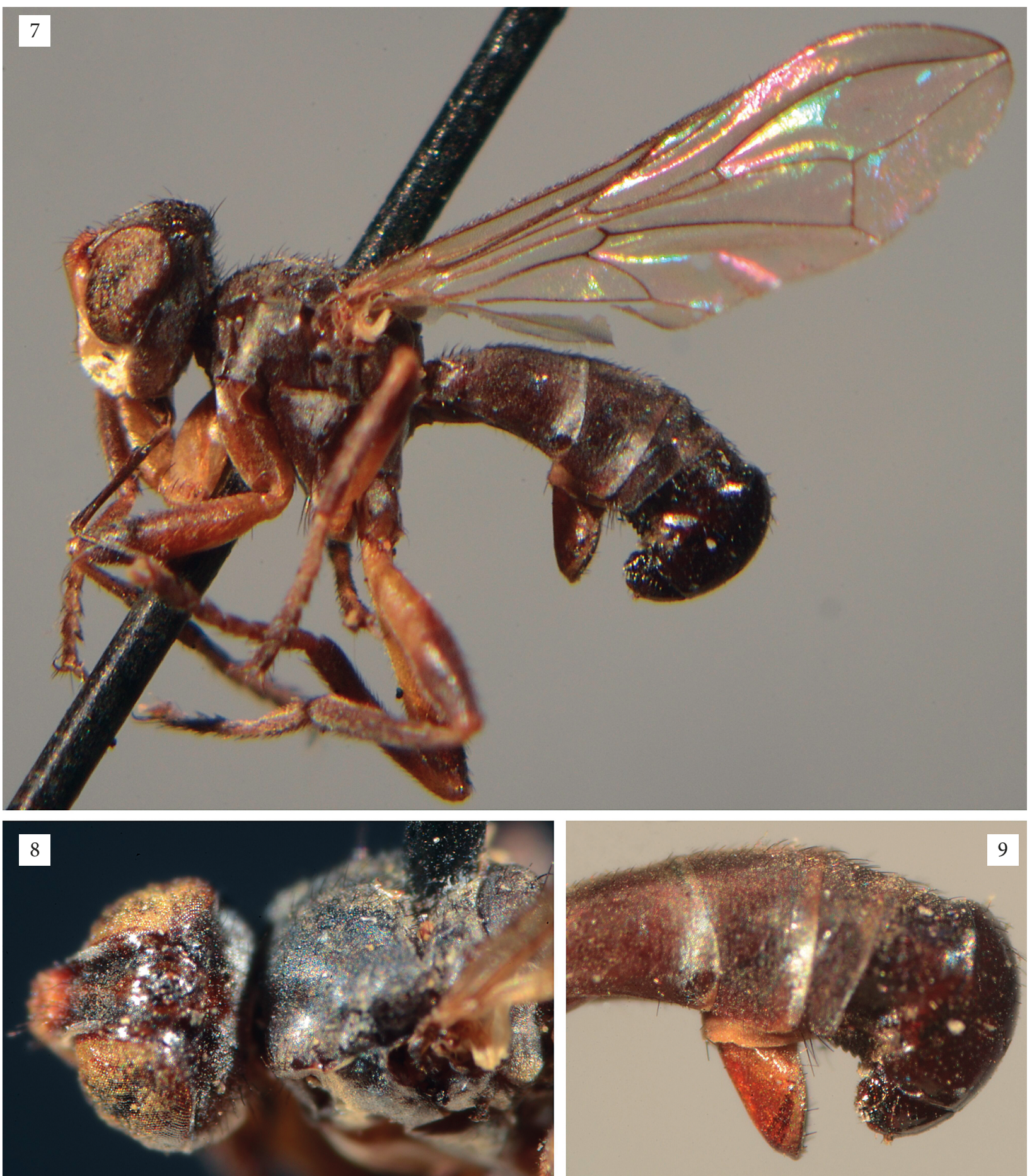

Figs 7-9: Thecophora caenovalva (KRöвER, 1916) (holotype). - 7 habitus, lateral view; - 8 head and scutum, dorsolateral view; -9 theca, lateral view 
(4) "Occemyia / unbestimmbar / caenovalva KRв. ? / O. KRöBer det. 1927”; (5) "Paratypus”; (6) “Typus”.

Other material examined: JAPAN: 1 , 26.iv.1999, Ehime Prefecture, Mount Kamegamori, leg. Y. MAETA, coll. Stuke; 1 \% , 6.viii.2013, Hiroshima Prefecture, Mount Ryuouzan, leg. Y. MAETA, coll. StukE; 1 \%, 29.ix.1982, Tottori Prefecture, Mount Daisen, det. as Thecophora abdominalis by R. MAcFARLANe, leg. Y. MAEtA, coll. STUKE.

Remarks: Thecophora caenovalva was previously only known from the locus typicus „Formosa: Tappani“ [Taiwan]. The records from Japan are therefore a remarkable extension of the known distribution. Due to the large spoon-like theca, mainly yellow legs and labium that is about as long as the maximum length of head, females of T. caenovalva can easily be distinguished from females of all other Thecophora species known from the Palaearctic Region. The record of Thecophora abdominalis (Chen, 1939) from Japan (MAETA \& MaCFARLANE 1993 ) requires confirmation and is very probably based on a misidentification.

\section{Acknowledgements}

I am grateful to Frank Menzel (Germany, Müncheberg), Yasuo Maeta (Japan, Matsue), and Miroslav Barták (Czech Republic, Prague) who loaned material. D. Clements (Great Britain, Cardiff) made several important comments in the manuscript and once again checked the English.

\section{Literature}

Cumming, J. M. \& Wood, D. M. 2009: Adult Morphology and Terminology. Pp. 9-50. - In: Brown, B. V.; Borkent, A.; Cumming, J. M.; Wood, D. M.; Woodley, N. E. \& Zumbado, M. A. (eds.). - Manual of Central American Diptera. Volume 1. - NRC Research Press, Ottawa. - ISBN 0660198339.

KröBer, O. 1916: Die Gattung Occemyia RoB.-Desv. Archiv für Naturgeschichte (Series A) 81 [1915](7): 93-107.

Maeta, Y. \& MacFarlane, R. P. 1993: Japanese Conopidae (Diptera): Their biology, overall distribution, and role as parasites of bumble bees (Hymenoptera, Apidae). Japanese Journal of Entomology 61: 493-509.

Stuke, J.-H. 2017: Conopidae (Diptera). Volume 15: World Catalogue of Insects. - E. J. Brill, Leiden: xxxviii + 354 pp. 